\title{
THE EVALUTION OF SUSTAINABLE DEVELOPMENT POLICIES OF AZERBAIJAN SINCE INDEPENDENCE: A FOUR-CAPITAL MODEL APPROACH
}

\author{
Tugba Orten Tugrul ${ }^{1}$, Kanan Karımlı ${ }^{2}$
}

Keywords: sustainable development, sustainable energy, four capital model, qualitative research, Azerbaijan

\begin{abstract}
This study aims to explore sustainable development achievements and shortcomings of Azerbaijan since independence by examining sustainability impacts of policies according to the Four Capital Model. Secondary data was collected by reviewing many sources including scholarly articles, reports from international organizations, pieces of legislation, policy papers and government publications recording progress on development goals. In addition, primary data was collected by conducting in-depth interviews with two policymakers and two private sector representatives. Findings demonstrates that while Azerbaijan has fared relatively well in social aspects of sustainable development, economy and environment are areas where much progress remains to be achieved. Specifically, oil dependence of the economy needs to be diversified, domestic and foreign investment needs to be stimulated, and health care and social protection systems needs to be improved. Regarding sustainable energy, the study recommends Azerbaijan to utilize its available renewable energy sources and continue improving energy efficiency.
\end{abstract}

\section{Introduction}

Sustainable development has received considerable attention from scholars and policymakers over the last decades. Along with the rest of the international community and policymakers over the last decades. Along with the rest of the international community, as a young developing nation, sustainable development stands an important target for the Republic of Azerbaijan. Azerbaijan, which was a former Soviet nation, gained its independence about a quarter century ago and

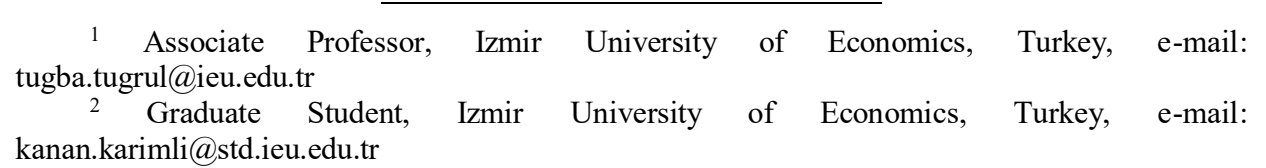


went through a turbulent process of development. After losing most of its industrial production capacity upon the break-up of the Union of Soviet Republics and living through a brutal war, Azerbaijan had to build new institutions, and an economic system considerably directed by the country's oil riches. Today's Azerbaijan is, thus, a country with an economy significantly depending on the oil exports, which bring volatile revenues as proved by the recent significant drop in prices starting from 2014. In summary, since independence, Azerbaijan has gone through a dynamic period of economic and political transition. While these changes have received scholarly attention (e.g., Aras, Suleymanov, and Zeynalov, 2012; Petri, Taube, Tsyvinski, 2002), there is a literature gap on the contribution of these changes in the pursuit of sustainable development. In other words, to what extent state policies have complied with the framework of sustainable development needs to be investigated. Therefore, this study aims to explore sustainable development achievements and shortcomings of Azerbaijan since independence by examining sustainability impacts of policies according to the Four Capital Model (Ekins and Medhurst, 2006). More specifically, the following research question is addressed:

To what extend do post-Soviet Azerbaijan policies contribute to the country's sustainable development achievements in terms of manufactured, social, human and natural capitals?

\section{The four - capital model in sustainable development evaluation}

Sustainable development became a ubiquitous concept in the last decades of the 20th century following the publication of "Our Common Future", a report published by the United Nations World Commission on Environment and Development (Brundtland Commission, 1987). It refers to "the development that meets the needs of the present without compromising the ability of future generations to meet their own needs" (Brundtland Commission, 1987: 37). As seen from the definition, the focus is on the intergenerational equity that emphasizes "fairness among generations in the use and conservation of the environment and its natural resources" (Weiss, 2013).

Ekins and Medhurst (2008) propose the Four Capital Model to evaluate the contribution of policies at different levels (global, international, national, regional and local) to sustainable development. The model is based on the classification of the capital (assets): manufactured capital, social capital, human capital and environmental capital. Manufactured capital refers to produced assets that are used to produce or facilitate the production of other goods and services. However, for this flow of goods to happen, there is a need for labor, social 
institutions, and natural resources, which accordingly correspond to the human capital, social capital, and the natural capital. Manufactured capital includes, such as, infrastructure, tools, and equipment. Social capital refers to social networks towards a cohesive society facilitating social and intellectual interactions, such as civil society, government institutions, and law-enforcement system. Physical and mental well-being, qualifications, education, and skills of workforce all qualify as the human capital. Natural capital predominantly refers to what is known as the natural resources, such as water, and sources of fossil fuel. The Four Capital Model postulates that human, financial, natural and manufactured capitals should be balances so that the use of one would not compromise another (Ekin and Medhurst, 2006).

To show how government policies may influence the balance of stocks of the four aforementioned types of capital, a sustainability assessment framework (SAF) was developed by Ekins and Medhurst (2006). To assess the impact of policies; first indicators for four capital stocks are determined, and then the impacts of policies regarding each indicator are identified as positive $(+)$, negative $(-)$, neutral $(*)$ and unknown $(\mathrm{n} / \mathrm{a})$ in the matrix. The number of $(+)$ and (-) shows the strength of the positive and negative effects, respectively. The impact on capital types is aggregated in summaries, which is made to both aggregate the impact of all policies on separate types of capital and of policies on all types of capital jointly.

\section{Methodology}

Exploratory research design is utilized to provide an overview of the Azerbaijan's developments in economic, social and environmental domains throughout the entire period of the independence. For studies on energy and energy-related phenomena, qualitative methods are more pertinent as they enable the exploration and understanding of the complex phenomena (Biresselioglu, Yildirim, Demir, and Tokcaer, 2017). Qualitative research methods such as interviews provide "interactivity, flexibility, sufficiency and appropriateness" and allow the collection of more fluid, not numerial type of information, which would be difficult to obtain through quantitative methods (Biresselioglu, Yildirim, Demir, and Tokcaer, 2017). Energy research literature calls for integrating social aspects of energy production, consumption and policies, and utilizing more human-centered methods of data collection (Sovacool, 2014). Secondary data was collected by reviewing a large number of sources to examine different dimensions of the issues under consideration. The sources analyzed include scholarly articles on concepts of sustainable development and energy, reports from international organizations, pieces of legislation, policy papers, 
government publications recording progress on development goals, data from government institutions. Then, primary data was collected by conducting four in-depth interviews with policymakers and private sector representatives in Azerbaijan (see Table 1 for details). The structured interviews were sent to respondents via e-mails between March and April 2018.

Table 1. Details of Interviewees

\section{Position}

\begin{tabular}{lll}
\hline Public & Sector & Senior Specialist at Fiscal Policy Division of the Budget \\
Representative I & Policy \& Macroeconomic Analysis Department of the \\
& Ministry of Finance of the Republic of Azerbaijan.
\end{tabular}

\begin{tabular}{lcl}
\hline $\begin{array}{l}\text { Public } \\
\text { Representative II }\end{array}$ & $\begin{array}{l}\text { Sector } \\
\text { of the Ministry of Economy of the Republic of } \\
\text { Azerbaijan. }\end{array}$ \\
\hline $\begin{array}{l}\text { Private } \\
\text { Representative I }\end{array}$ & Sector $\begin{array}{l}\text { Deal Advisory Executive at the Baku Office of KPMG, a } \\
\text { BIG Four member global professional services company. }\end{array}$ \\
\hline $\begin{array}{l}\text { Private } \\
\text { Representative II }\end{array}$ & Sector CleanTech Associate for Schneider Electric EMEA. \\
\hline
\end{tabular}

To adjust the SAF for the purposes of this research, first clusters of indicators were framed against which the change in stocks of capital are assessed. Indicators were derived from the sustainable development evaluation indicators suggested by Ekin and Medhurst (2008). Then, since current study aims at providing a holistic assessment of the sustainability of Azerbaijan's development since independence, policies were grouped as economic, social and environmental. While many policies have an overarching scope, main sustainability focus was taken into account. Finally, sustainability impacts of policies implemented since independence of Azerbaijan were assessed separately in terms of each stock of the Four Capital Model.

\section{Findings}

\subsection{Sustainability Assessment of Economic Policies}

Azerbaijan gained its independence in 1991 after being under the Soviet Union rule for seven decades. The first years of independence in Azerbaijan were marred with the economic and political chaos. Until 1996, Gross Domestic Product (GDP) of the country showed only a downward trend; declining from \$ 
8.792 million in 1991 to $\$ 4.991$ million in 1992 , reaching the lowest point in 1995, when it was $\$ 3.052$ million (World Bank, 2018). Agricultural production and manufacturing decreased from $77.5 \%$ in 1990 to $32.7 \%$ in 1995 . Hyperinflation was another problem. As part of the transition to the market economy, it was important to set off the price liberalization. However, it carried the risk of the hyperinflation. While, the rate of inflation in 1992 was $46.2 \%$, it started skyrocketing to $1128 \%$ and $1662 \%$ in 1993 and 1994, respectively. The 4-digit inflation figure was related to the decision of the money-printing to cover the budget deficit. Towards the mid-90s, the economy started stabilizing. One of the drivers for this was the Production Sharing Agreement (PSA) signed in 1994 - the Agreement on the Joint Development and Production Sharing for the Azeri and Chirag Fields and the Deep Water Portion of the Gunashli Field in the Azerbaijan Sector of the Caspian Sea - to exploit the oil reserves of the country. The PSAs brought the much-needed revenues to the economy; the value of the deal estimated to be $\$ 60$ billion, strengthening the fiscal position of the government. The economy started recovering and growing, thus expanding the economic capital. The revenues were invested on the social sector, mainly education and health, consequently positively impacting the social capital as well. There was no direct tangible impact on the natural capital. Thus, if aggregated overall, the PSAs positively influenced the achievement of sustainability. In 1996, Azerbaijan took loans from the International Monetary Fund (IMF), conditional on implementation of Structural Reforms (SRs). In support to the reforms, Azerbaijan received about $\$ 577$ million worth loans from the IMF in 1995-2005 (CBC, 2017). The reforms allowed restoring macroeconomic stability with the hyperinflation going down (Suleymanov and Aliyev, 2015). This significantly improved the economic situation in the country. The second half of the 90s was marked as the recovery period for the economy; for the first time since independence recorded a positive GDP growth $(1.3 \%)$ in 1996 (World Bank, 2018). In addition, the decrease in hyperinflation brought down the depreciation of people's income, positively influencing the social capital as well. On the human capital and environmental capital, there was little to no tangible impact.

The end of 2014 gave a foreboding about the upcoming tense times for the economy of the oil revenues-dependent nations, Russia, Kazakhstan, Venezuela and Azerbaijan, because of the decline in oil prices. In 2014, oil accounted for $50 \%$ of the budget revenues, $39 \%$ of GDP, over $90 \%$ of the exports (with both oil and oil products exports) (State Oil Fund of Azerbaijan, 2015). In 2016, government prepared Strategic Roadmaps (SRMs) for the national economy and main economic sectors including oil and gas industry (Deloitte Azerbaijan, 2016). The SRM on the national economy identified the fiscal sustainability and 
adoption of sustainable monetary policy as targets. These, in turn, positively influenced the economic capital. Inflation rate was $18.6 \%$ and the poverty rate was $12.5 \%$ in 2016 (CESD, 2017). Other sector-specific SRMs, such as the roadmap on the tourism, agriculture, small and medium size enterprises and heavy industry, aimed to contribute to the diversification of the economy, the economic growth and the reduction of unemployment which has a positive effect on the human capital as well. Through the reduction in the rate of emigration, such policies positively affected the social capital. While on the natural capital, there was little to no effect from the implementation of many of these roadmaps, such as, oil and gas sector and the heavy industry may exert pressure on the environment by, such as, adding up to problems regarding pollution and waste disposal, consequently eroding the natural capital. On the other hand, strategies to increase energy efficiency and support transition to alternative energy sources may result in a positive impact on the natural capital. Similarly, the economic capital as the improvement of the energy efficiency may reduce energy losses and benefit the economy. Overall, the economic policies contributed to the sustainable development; however, the balancing with the natural capital requires more attention. Table 2 presents the details of the sustainability assessment of economic policies of Azerbaijan since independence.

Table 2. Sustainability Assessment Matrix for Economic Policies

\begin{tabular}{|l|l|l|l|l|l|}
\hline \multicolumn{7}{|l|}{ Sustainability Impacts } \\
\hline & $\begin{array}{l}\text { Economic } \\
\text { capital }\end{array}$ & $\begin{array}{l}\text { Social } \\
\text { capital }\end{array}$ & $\begin{array}{l}\text { Human } \\
\text { capital }\end{array}$ & $\begin{array}{l}\text { Natural } \\
\text { capital }\end{array}$ & Summary \\
\hline PSA & +++ & ++ & + & $*$ & ++ \\
\hline SRs & +++ & + & $*$ & $*$ & ++ \\
\hline SRMs & +++ & +++ & +++ & + & +++ \\
\hline Summary & +++ & ++ & ++ & $*$ & ++ \\
\hline
\end{tabular}

\subsection{Sustainability Assessment of Social policies}

The collapse of the centralized Soviet economy and the outbreak of the Nagorno-Karabakh confronted Azerbaijan with a number of social challenges including unemployment, high poverty rates and poor healthcare system. In 1995 , the $79.2 \%$ of the internally displaced persons lived below the poverty line, a higher figure compared to the national average of $68.1 \%$ in 1995 (Ministry of Foreign Affairs of the Republic of Azerbaijan, 2018). To address the situation of the displaced population, in 1998, the State Program on the Solution to Problems 
of the Refugees and Internally Displaced Persons (SPSPRI) was adopted. The program aimed at improving living conditions of the refugees addressing problems, such as unemployment, housing and infrastructure (Azərbaycan Respublikasının Prezidenti, 2003), which contributed to the social capital and human capital. In 2003, following the arrival of the windfall of oil revenues, Azerbaijan implemented its first poverty reduction strategy - State Program on Poverty Reduction and Economic Development (SPPRED). The policy had a broad focus encompassing social sector and overall economy. In the period spanning the years of the implementation of the SPPRED, per capita GDP growth rate doubled, $26.4 \%$, minimum salaries increased 5.5 times, pensions rose 2.2 times, over 340 thousand new jobs were added to the labor market and poverty rate fell from over $46 \%$ to below $30 \%$ (UNICEF, 2006). The state strategies addressing social issues, such as unemployment, health, education and problems of the displaced, significantly strengthened the social capital of the country. In addition, the increased investment on education by the government contributed to the human capital. It also targeted the macroeconomic stability thus contributing to the economic capital. However, the natural capital remained disaffected. In 2006, a new national poverty reduction strategy - the State Program on the Poverty Reduction and Sustainable Development (SPPRSD) was introduced sharing similar strategic goals with SPPRED, such as poverty reduction, social protection, and condition of the displaced. This program went further touching the gender equality. Thus, the social capital was strengthened further as was the economic capital by the macroeconomic stability. The SPPRSD also stated the importance of the compliance with the environmental sustainability of the state program, although it was not translated into concrete measures. The investment of newly-gained financial resources from oil revenues contributed significantly to the poverty reduction. By 2007 , the poverty rate had dropped down to $15.8 \%$ from $49 \%$ in 2001 (International Labour Organization, 2016). This number decreased to $4.9 \%$ at the end of the realization of the program (Ahmadov, 2017). In addition, youth unemployment declined to $13.4 \%$ from 22\% (Ahmadov, 2017). Between 2003 and 2015, about 1.5 million new jobs were added to the economy, which contributed to the poverty reduction efforts. (ILO, 2016). During 2000-2008, the minimum wage rose by about $6700 \%$. In the same period, the average salary grew to 268 manats from 41 manats. The rate of decline in poverty was higher in the urban areas than the rural areas. Thus, the government policies were both redistributive and progrowth (World Bank, 2010). Income inequality dropped to 36.5\% in 2001 from $31 \%$ in 2008 according to the Gini index (World Bank, 2010). As part of the social spending, the health expenditures of the government increased as well in this period. From 2006 to 2010, the healthcare expenses of the state went up to 
429 million manats from 115 million manats. In 2006-2010, the number of doctors increased even though their number per 10000 people declined. The wages of the medical personnel rose by 5 times (World Health Organization, 2015). The improved healthcare was followed by the improvement in the life expectancy, drop in the maternal mortality and infant mortality rates. Table 3 provides a summary of the sustainability assessment of social policies of Azerbaijan since independence.

Table 3. Sustainability Assessment Matrix for Social Policies

\begin{tabular}{|l|l|l|l|l|l|}
\hline & \multicolumn{5}{|l|}{ Sustainability Impacts } \\
\hline & $\begin{array}{l}\text { Economic } \\
\text { capital }\end{array}$ & $\begin{array}{l}\text { Social } \\
\text { capital }\end{array}$ & $\begin{array}{l}\text { Human } \\
\text { capital }\end{array}$ & $\begin{array}{l}\text { Natural } \\
\text { capital }\end{array}$ & Summary \\
\hline SPSPRI & $*$ & +++ & ++ & $*$ & ++ \\
\hline SPPRED & ++ & +++ & ++ & $*$ & +++ \\
\hline SPPRSD & + & +++ & +++ & $*$ & +++ \\
\hline Summary & ++ & +++ & + & $*$ & ++ \\
\hline
\end{tabular}

\subsection{Sustainability Assessment of Environmental policies}

Following independence, Azerbaijan prohibited a wide range of environmental challenges from the Soviet Union due to its industrial past. There were problems in some of the areas, such as, air pollution, waste disposal and treatment, water quality, and deforestation. The first major policy tool to address these issues was the National Environmental Action Plan (NEAP), which was adopted in 1998 and then revised in 2003. The action plan was consisted of 32 objective covering a broad spectrum of issues including air and water quality, deforestation, Caspian coastal zone damage, and soil contamination. The realization of all these actions in total would have demanded 42.5 million dollars, which would make up $1 \%$ of the state budget. However, by 2003 , only about $20 \%$ of the envisaged actions had been carried out (UNECE, 2004). The progress was mainly achieved in the development of environmental institutional regulation, which in turn benefitted the natural capital in the country. Through the positive impact on the natural capital with the improvement in areas, such as soil contamination, air pollution, the social capital in the country also advantaged as the living standards improved. The Comprehensive Action Plan on Improvement of the Environmental Situation (CAPIES) aimed at tackling the industrial pollution in the country and entailed measures of cleaning several industrially polluted lakes in the Absheron Peninsula. Consequently, the Bibiheybat zone was cleaned as was half of the Boyukshor lake where the cleanliness of its water was restored (President of the Republic of Azerbaijan, 
2006). This action plan, as the NEAP, firstly benefitted the natural capital, which is followed by the social and human stocks. In 2003, the National Program on the Restoration and Expansion of Forests (NPREF) was adopted. In the completion of the national program, 60 thousand hectares of forests had been restored or planted. In the period of 2003-2008, 1087 hectares of forestry was planted in Baku (Bədəlov, 2009). In 2004, the State Program on Use of Alternative and Renewable Energy Sources (SPUARES) aimed at promoting green energy, and thus, enhancing the natural capital. The program included tasks as identification of the country's potential in this domain, ensuring the energy security through the use of alternative and renewable energy (President of the Republic of Azerbaijan, 2004). The share of the renewables has remained marginal in primary energy production during the period of 2007-2014 (Hajiyev, Dimadama, Timotheou, \& Gross, 2015). In addition, the share of the renewables remained small in the final consumption of the energy products, where natural gas, petroleum products and electricity accounted for over $90 \%$ of the total consumption. Table 4 shows the sustainability assessment of social policies of Azerbaijan since independence.

Table 4. Sustainability Assessment Matrix for Environmental Policies

\begin{tabular}{|l|l|l|l|l|l|}
\hline & \multicolumn{5}{|l|}{ Sustainability Impacts } \\
& $\begin{array}{l}\text { Economic } \\
\text { capital }\end{array}$ & $\begin{array}{l}\text { Social } \\
\text { capital }\end{array}$ & $\begin{array}{l}\text { Human } \\
\text { capital }\end{array}$ & $\begin{array}{l}\text { Natural } \\
\text { capital }\end{array}$ & Summary \\
\hline NEAP & + & + & ++ & ++ & ++ \\
\hline CAPIES & + & + & ++ & ++ & ++ \\
\hline NPREF & $*$ & $*$ & + & ++ & ++ \\
\hline SPUARES & + & $*$ & + & ++ & + \\
\hline Summary & + & $*$ & ++ & ++ & ++ \\
\hline
\end{tabular}

\section{Conclusion}

The sustainability impact analysis of policies illustrates that economic capital benefitted most. After independence, the economy once centrally planned by the government was in total ruins. Structural reforms and other policies created a solid macroeconomic framework, established pillars for the emergence of a market economy through privatization and price liberalization. Attracting foreign investment mainly in the oil sector helped the country obtain the muchneeded financial resources. All these, which were translated into the growth of the economic capital, were central to achievement of sustainable development of economy though not sufficient as problems in areas such as financial regulation, 
unemployment, and corruption remained not well addressed. Therefore, the economic pillar of sustainable development entails building of a diversified, transparent economy with strong regulatory institutions and solid macroeconomic ground.

After economic capital, social capital benefitted most from the state policies. The collapse of the Soviet Union brought an end to the social protection policies of that era. Unemployment soured and the funding to the social protection of the populace declined significantly in the first years of independence. However, with the arrival of the petroleum revenues, more resources were allocated to the social defense as well increasing social capital. Unemployment declined from rates in the 90s. Public investment was boosted through infrastructure projects including construction of roads, hospitals, schools etc. Also, pensions and other social benefits rose too. On an individual basis, all these benefitted the human capital as well as living standards improved. This was positively reflected on sustainable development of the country as the social dimension is one of three dimensions of sustainable development. However, as problems with the poor quality of public education and healthcare system, social protection system and other problems linger, much has to be made before the country can achieve sustainable development. Therefore, the social pillar appertains to building an effective healthcare and education and social protection systems.

The environmental capital benefitted least of all from the state policies following independence achievement. The spillover effect of economic and social policies on the environmental capital was mostly minimal. Implemented policies mainly targeted establishment of an environmental regulation system. In areas such as air pollution, pollution of the Caspian Sea, deforestation, salinization, transition to the renewable energy, improvement of energy efficiency, small progress left much to be desired regarding achievement of environmental sustainability. Therefore, the environmental pillar concerns achievement of energy sustainability through renewable energy, energy efficiency improvement, addressing of perennial issues, such as, industrial pollution and Caspian Sea contamination.

\section{References:}

1. Ahmadov, A. (2017). Azerbaijan - 2030: Transition from the MDGs to the SDGs. United Nations. Retrieved from https://sustainabledevelopment.un.org/content/documents/25569 AZERBAIJAN VNR PPT.pdf 
2. Aras, O. N., Suleymanov, E., \& Zeynalov, A. (2012). Azerbaycanın Enerji Kaynakları Gelirlerinin Ülke Ekonomisine Etkisi (Azerbaijan's Energy Source Revenues and Their Effect on the Economy of the Country). Available at SSRN 2194173.

3. Azərbaycan Respublikasının Prezidenti. (2003). 2003-2005-Ci Illar Üçün Azərbaycan Respublikasinda Yoxsulluğun Azaldilmasi Və Iqtisadi Inkişaf Üzrə Dövlat Proqrami. Retrieved from http://www.e-qanun.az/framework/1954

4. Bədəlov. (2009). Meşələrin barpa edilməsina va artırllmasına dair Milli Proqram (2003-2008-ci illar) ugurla başa çatdırıldı. Azerbaijan National Library. Retrieved from http://www.anl.az/down/meqale/xalqqazeti/xalqqazeti mart2009/72283.htm

5. Biresselioglu, M. E., Yildirim, C., Demir, M. H., \& Tokcaer, S. (2017). Establishing an energy security framework for a fast-growing economy: Industry perspectives from Turkey. Energy Research \& Social Science, 27, 151-162. https://doi.org/10.1016/j.erss.2017.03.007

6. Brundtland Commission. (1987). Report of the World Commission on Environment and Development: Our Common Future. United Nations. Retrieved from https:/www.are.admin.ch/are/en/home/sustainable-development/internationalcooperation/2030agenda/un-_-milestones-in-sustainable-development/1987-brundtland-report.html

7. CESD. (2017). Azerbaijan Economy in 2016; Brief Overview. Retrieved from http://cesd.az/new/wpcontent/uploads/2017/02/Azerbaijan_Economy_in_2016.pdf

8. Ekins, P., \& Medhurst, J. (2006). The European Structural Funds and Sustainable Development: A Methodology and Indicator Framework for Evaluation. Retrieved from http://sti.uem.mz/documentos/d_sustentavel/desenvolvimentosustentavel_04.pdf

9. Elkins, P., \& Medhurst, J. (2008). The four-capital method of sustainable development evaluation. European Environment, 65. https://doi.org/10.1002/eet.471

10. Hajiyev, S., Dimadama, Z., Timotheou, A., \& Gross, Z. (2015). Energy Efficiency: View from Azerbaijan, Germany and Israel. SAM Review.

11. International Labour Organization. (2016). Decent Work Country Programme of the Repubiic of Azerbaijan for 2016-2020. Retrieved from http://www.ilo.org/wcmsp5/groups/public/---ed mas/--program/documents/genericdocument/wcms 562106.pdf

12. Ministry of Foreign Affairs of the Republic of Azerbaijan. (2018). Refugees and IDPs. Retrieved from http://www.mfa.gov.az/en/content/117

13. Petri, M., Taube, G., \& Tsyvinski, A. (2002). Energy sector quasi-fiscal activities in the countries of the former Soviet Union (No. 2002-2060). International Monetary Fund.

14. President of the Republic of Azerbaijan. (2004). The State Program on Use of Alternative and Renewable Energy Sources. Retrieved from http://www.inogate.org/documents/AZ 20041021 State Program on Renewabl e Energy of Azerbaijan Republic.pdf

15. President of the Republic of Azerbaijan. (2006). On approving the Comprehensive Action Plan on improving the environmental situation in the Azerbaijan Republic 
for 2006-2010. Retrieved from www.fhn.gov.az/uploads/legislation/eng/serencamlar/28.09.2006p.doc

16. Sovacool, B. K. (2014). What are we doing here? Analyzing fifteen years of energy scholarship and proposing a social science research agenda. Energy Research \& Social Science, 1, 1-29. https://doi.org/10.1016/j.erss.2014.02.003

17. State Oil Fund of Azerbaijan. (2015). Annual Report 2014. Retrieved from http://www.oilfund.az/uploads/annual-2014en.pdf

18. Suleymanov, E., \& Aliyev, K. (2015). Macroeconomic Analysis and Graphical interpretation Of Azerbaijan Economy In 1991-2012. Retrieved from https://mpra.ub.uni-muenchen.de/65306/1/MPRA paper 65286.pdf

19. UNECE. (2004). Azerbaijan: Environmental Performance Reviews. Retrieved from http://www.unece.org/fileadmin/DAM/env/epr/epr_studies/azerbaijan.pdf

20. UNICEF. (2006). State Program on Poverty Reduction and Sustainable Development. Retrieved from http://planipolis.iiep.unesco.org/sites/planipolis/files/ressources/azerbaijan_mdgprsp 2006-2015.pdf

21. Weiss, E. B. (2013). Intergenerational Equity, Oxford Public International Law. Retrieved from http://opil.ouplaw.com/view/10.1093/law:epil/9780199231690

22. World Bank. (2010). Azerbaijan Living Conditions Assessment Report. Retrieved from https://openknowledge.worldbank.org/bitstream/handle/10986/2836/528010ESW0 GRAY1C0disclosed031241101.pdf?sequence $=1 \&$ isAllowed $=\mathrm{y}$

23. World Bank. (2018). Indicators. Retrieved from https://data.worldbank.org/indicator

24.World Health Organization (2015). Azerbaijan. Retrieved from http://apps.who.int/gho/data/node.country.country-AZE

C) 2020 by the authors. Licensee UAIC, Iasi, Romania. This article is an open access article distributed under the terms and conditions of the Creative Commons Attribution (CC BY-NC-ND) license (https:// creativecommons.org/licenses/by-nc-nd/4.0). 